University of Nebraska - Lincoln

DigitalCommons@University of Nebraska - Lincoln

Economics Department Faculty Publications

Economics Department

August 2005

\title{
Do higher tipped minimum wages boost server pay?
}

John E. Anderson

University of Nebraska-Lincoln, JANDERSON4@UNL.EDU

ORN B. BODVARSSON

University of Nebraska-Lincoln, OBODVARSSON2@UNL.EDU

Follow this and additional works at: https://digitalcommons.unl.edu/econfacpub

Part of the Economics Commons

Anderson, John E. and BODVARSSON, ORN B., "Do higher tipped minimum wages boost server pay?" (2005). Economics Department Faculty Publications. 33.

https://digitalcommons.unl.edu/econfacpub/33

This Article is brought to you for free and open access by the Economics Department at DigitalCommons@University of Nebraska - Lincoln. It has been accepted for inclusion in Economics Department Faculty Publications by an authorized administrator of DigitalCommons@University of Nebraska - Lincoln. 


\title{
Do higher tipped minimum wages boost server pay?
}

\author{
John E. Anderson and Örn B. Bodvarsson \\ Department of Economics, CB A 340, \\ University of Nebraska-Lincoln, PO Box 880489, \\ Lincoln, NE 68588-0489, USA \\ Corresponding author-O. Bodvarsson, \\ email obodvarsson2@unl.edu
}

\begin{abstract}
Do tipped servers in states with higher tipped minimum wages earn more, ceteris paribus, than servers elsewhere? Using 1999 data on waitpersons and bartenders, little evidence is found of a premium to servers in states with more generous minimum wages.
\end{abstract}

\section{Introduction}

Most tipped servers in the USA earn a wage, and often the server's wage equals the minimum wage less tips. The "tip credit" is the amount of tips that employers may deduct from the minimum wage when determining the wage to pay. The minimum wage the employer must pay, called the "tipped minimum wage," is the non-tipped minimum wage less the tip credit. Total pay (wage plus tips) must at least equal the non-tipped minimum wage. The federal tip credit is currently $\$ 3.02$ and may be exercised by businesses with gross sales exceeding $\$ 500,000$ per year that are only engaged in intrastate commerce. Thirty-four states have tip credit policies, 26 differing from federal policy. ${ }^{1}$ The federal credit supercedes the state credit if the latter is less favorable to the employee. The effects of tip credit policies on labor market participants have received almost no attention among labor economists. ${ }^{2}$

Do servers earn more in states with higher tipped minimum wages? We hypothesize no ceteris paribus premium to such servers. The reason is that the national market for servers is very competitive and we contend that it will equalize pay between states. Servers in states with lower tipped minimum wages may migrate to states with higher wages, or businesses in states with higher tipped minimum wages may relocate to states with lower wages. The resulting adjustments in server demand and supply will dissipate any interstate ceteris paribus differences in pay. We test this hypothesis using 1999 state-level data on hourly compensation of waitpersons and bartenders.

\section{Test}

Our methodology accounts for the possibility that the determinants of pay are contingent upon the state's tip credit policy. Hence, we used a two-step selection model. First, we used PROBIT to estimate policy adoption and then we estimated pay conditional upon policy adoption. Our data set includes, for each of the 50 states, two observations, one for restaurant waitpersons and one for bartenders, during 1999. The dependent variable is average hourly pay (wage plus tips). Independent variables include: (1) demographic and human capital measures; (2) state tax, minimum wage, and tip credit policies; and (3) characteristics of the state's restaurant and bar industries. Compensation data were obtained from the "Wages by Area and Occupation" file on the BLS website (http://www.bls.gov/oes/1999). De-

1 Currently, the tipped minimum wage ranges from $\$ 1.59$ in Kansas to $\$ 7.16$ in Washington.

2 The only published research we are aware of is by Wessels $(1993,1997)$, who used Census of Retail Trade data to estimate the effects of tipped minimum wages on the volume of server employment. 
Table 1. State tip credit policies

\begin{tabular}{ll}
\hline Category & States \\
\hline $1 \quad$ States with no minimum wage and tip credit & AL, AZ, FL, GA LA, MS, SC, TN \\
2 & $\begin{array}{l}\text { States where the minimum wage and/or tip credit } \\
\text { are less favorable than the federal provision(s) }\end{array}$ \\
$\begin{array}{l}\text { States with minimum wage and tip credit } \\
\text { identical to the federal provisions }\end{array}$ & KS, NM OH, VA \\
$\begin{array}{l}\text { States where the minimum wage and/or tip credit } \\
\text { are more favorable to the tipped employee than } \\
\text { the federal provision(s) }\end{array}$ & CO, IN, KY, NE, NC, SD, TX, WY \\
$\begin{array}{l}\text { States with no tip credits and minimum wages } \\
\text { that exceed the federal minimum wage }\end{array}$ & AR, CT, DE, HI, IA, ID, IL, MA, MD, ME, \\
\hline
\end{tabular}

Source: US Department of Labor - http://www.dol.gov/esa/programs/whd/state/tipped.htm

Table 2. Descriptive statistics

\begin{tabular}{|c|c|c|c|c|}
\hline Variable & Mean & SD & High & Low \\
\hline Percentage of restaurants (bars) exempt from minimum wage laws & 25.90 & 30.94 & 100 & 0 \\
\hline Minimum income tax rate & 2.37 & 1.71 & 6 & 0 \\
\hline No sales tax & 0.92 & 0.273 & 1 & 0 \\
\hline No income tax & 0.18 & 0.386 & 1 & 0 \\
\hline Percentage of residents that are white & 79.47 & 12.90 & 96.8 & 24.3 \\
\hline Ratio of percentage of residents $45-64$ to $18-44$ & 57.27 & 0.046 & 66.5 & 40.2 \\
\hline Percentage of high school graduates & 85.48 & 3.94 & 91.8 & 77.1 \\
\hline
\end{tabular}

mographic and human capital measures were obtained from the 2002 Statistical Abstract of the United States (http://www.census.gov/statab/www). Information on each state's tax policy and minimum wage law came from the federal and state departments of labor. Finally, data on the state's restaurant and bar industries came from the National Restaurant Association and the Bureau of Economic Analysis (http://www.bea.gov).

States were grouped on the basis of how favorable their minimum wage laws are to tipped employees. Each state is classified into one of 5 categories, shown in Table 1. Category 1 includes states with no minimum wage laws. Category 2 includes states that have both minimum wages and tip credits and at least one of these is less favorable to servers than is federal law. For example, Kansas has a minimum wage of \$2.65 for non-tipped employees (applies only to small firms) and $\$ 1.59$ otherwise. Category 3 includes states with minimum wage and tip credit provisions identical to federal law. Category 4 includes states where at least one provision is more favorable to the tipped employee, and Category 5 includes states that disallow tip cred- its and have minimum wages that exceed the federal wage.

Table 2 shows descriptive statistics. There were 2,392,000 bartenders and waitpersons (85\% were waitpersons) with pay averaging $\$ 6.69$. This averaged about $30 \%$ more than the federal non-tipped minimum wage, indicating that hourly tips were high enough to allow employers to take the maximum federal credit. We included two controls for each state's restaurant and bar industries: (1) the percent of firms exempted from state and federal minimum wage laws; and (2) restaurant revenues as a proportion of Gross State Product (GSP). We controlled for income and sales tax policies with: (1) two dichotomous variables: no income tax (yes $=1$ ), and no sales tax (yes $=1$ ); and (2) the minimum income tax rate, the likely rate affecting servers. Remaining variables include the state's age distribution and the proportions of the state's residents that are male, white, have completed high school, and are covered by a union contract. We controlled for the state's age distribution by computing the proportion of residents 45 to 64 years of age to the proportion 18-44 years of age. 
Table 3. PROBIT results for tip credit adoption

\begin{tabular}{lll}
\hline Variable & Estimated coefficient & Marginal effect \\
\hline Median pay & $0.2239(0.3387)$ & $0.1553 \mathrm{E}-01(0.2513 \mathrm{E}-01)$ \\
Income distribution skewness & $3.3366(2.1469)$ & $0.2314(0.1764)$ \\
No income tax & $-2.1904^{\mathrm{a}}(0.7215)$ & $-0.1519^{\mathrm{b}}(0.7889 \mathrm{E}-01)$ \\
No sales tax & $-0.8222(0.6869)$ & $-0.5702 \mathrm{E}-01(0.5859 \mathrm{E}-01)$ \\
Minimum wage & $-0.8084^{\mathrm{a}}(0.2175)$ & $-0.5605 \mathrm{E}-01^{\mathrm{c}}(0.3018 \mathrm{E}-01)$ \\
Restaurant sales as share of GSP & $-2.9692(28.9536)$ & $-0.2059(2.0195)$ \\
Share of firms exempt from minimum wage & $-0.1088 \mathrm{E}-01(0.9617 \mathrm{E}-02)$ & $-0.7547 \mathrm{E}-03(0.6604 \mathrm{E}-03)$ \\
\hline
\end{tabular}

Notes: Standard errors are in parentheses. Superscripts a, b and c indicate significance at the 1\%, 5\% and 10\% significance levels, respectively

Table 4. Coefficient estimates for mean hourly pay

\begin{tabular}{llc}
\hline Variable & OLS & Sample selection \\
\hline Constant & $-4.7692^{\mathrm{a}}(4.6531)$ & $4.6499(5.0267)$ \\
No income tax & $0.8181 \mathrm{E}-01(0.1397)$ & \\
No sales tax & $0.1324(0.2035)$ & $0.6248^{\mathrm{a}}(0.9048 \mathrm{E}-01)$ \\
Bartenders & $-0.1420(1.2295)$ & $-0.1266(1.213)$ \\
Age & $0.2567 \mathrm{E}-01(0.1620 \mathrm{E}-01)$ & $0.4946 \mathrm{E}-01^{\mathrm{a}}(0.1597 \mathrm{E}-01)$ \\
High school graduation percentage & $0.2011^{\mathrm{b}}(0.9516 \mathrm{E}-01)$ & $-0.3120 \mathrm{E}-01(0.1076)$ \\
Male percentage & $0.4496 \mathrm{E}-01^{\mathrm{a}}(0.1190 \mathrm{E}-01)$ & $0.3073 \mathrm{E}-01^{\mathrm{a}}(0.1028 \mathrm{E}-01)$ \\
Union representation percentage & $-0.2096 \mathrm{E}-01^{\mathrm{a}}(0.4784 \mathrm{E}-02)$ & $-0.2080 \mathrm{E}-01^{\mathrm{a}}(0.4018 \mathrm{E}-02)$ \\
White percentage & $0.3875 \mathrm{E}-01(0.3198 \mathrm{E}-01)$ & $0.6301 \mathrm{E}-01^{\mathrm{b}}(0.3058 \mathrm{E}-01)$ \\
Minimum income tax rate & $-0.2169(0.1921)$ & $-0.2238(0.1665)$ \\
Category 2 states & $-0.5345 \mathrm{E}-01(0.1512)$ & $-0.2889 \mathrm{E}-02(0.1341)$ \\
Category 3 states & $-0.5942 \mathrm{E}-03(0.2364 \mathrm{E}-03)$ & $-0.1148 \mathrm{E}-03(0.2064 \mathrm{E}-03)$ \\
Category 4 states & $0.7820 \mathrm{E}-01(0.3230)$ & $1.3445^{\mathrm{a}}(0.4581)$ \\
Category 5 states & $0.8849 \mathrm{E}-07(0.2186 \mathrm{E}-02)$ & $0.2764(0.2751)$ \\
Exempt firms & 0.5634 & 0.5883 \\
Inverse mills ratio & & \\
Adjusted $R^{2}$ & &
\end{tabular}

Notes: Standard errors are in parentheses. Superscripts a and b indicate significance at the $1 \%$ and $5 \%$ significance levels, respectively.

Table 3 shows PROBIT results, where the dependent variable is one for each state that has adopted a tip credit, and zero otherwise. This equation includes median hourly pay and mean hourly pay divided by the median, a skewness measure. Median pay has no effect on adoption of a tip credit, as does skewness. States without an income tax are less likely to adopt, but there is no effect from the lack of a state sales tax. The higher the state's minimum wage, the less likely it will be to adopt. $^{3}$

Table 4 shows OLS and sample selection estimates. According to OLS, none of the minimum wage and tip credit regimes appear to affect pay, whereas the sample selection estimates indicate that only workers in Category 5 states are paid a small premium relative to work- ers in states where there are no minimum wage laws. We conclude that, for the most part, servers in those states with higher tipped minimum wages appear to have no income advantage over servers elsewhere. States with policies designed to boost the incomes of servers, often the lowest paid occupations, will find that those policies are generally ineffective.

\section{References}

Wessels, W. J. (1993) The minimum wage and tipped employees, Journal of Labour Research, 14, 213-26.

Wessels, W. J. (1997) Minimum wages and tipped servers, Economic Inquiry, 35, 334-49. 